\title{
Creative profile of undergraduate engineering in a Federal University
}

\author{
Mario Orestes Aguirre González, Klinsmann de Paiva Cardone, Maria Emília Morkis Siqueira, \\ Técia de Lima Silva, Amanda Freire, Dayse da Mata Oliveira Souza \\ Universidade Federal do Rio Grande do Norte \\ e-mails: mario@ct.ufrn.br; klinsmanncardone@hotmail.com; mariaemiliasiq@gmail.com; tecia-lima@hotmail.com; a._freire@hotmail.com; dayse@ufrnet.br
}

\begin{abstract}
The creative potential development should take place in line with the professional training, which has its main foundation at schools, universities and society. Knowing the profile of creative people becomes fundamental, since current researches indicate creativity as a skill that can be developed when stimulated. The paper aims to identify the creative profile of undergraduate students of the courses of Civil and Industrial Engineering of a Federal University and analyze their evolution during the academic formation. A structured questionnaire was administered to 382 students. Taking into account the proposed by Oech, whom classifies the creative person in Explorer, Artist, Judge and Warrior, we can conclude that students of these Engineerings prevails the profiles Judge and Warrior. From the results, one considers the need to integrate in the pedagogical practices, curriculum and programs of disciplines, activities that encourage creative development for Explorer and Artist profiles, since the labor market and society demand for engineers with technical knowledge and creative skills that leverage innovations, with a high degree of novelty, in these organizations.
\end{abstract}

Keywords: creativity, creative potential, creative profile, engineering students.

\section{Introduction}

Face of technological changes, as evidenced in recent decades, the discussion on the concept of creativity and the factors that influence it was deepened, due to the importance of this skill for the process of innovation in organizations. However, this concept is complex and poorly known, as it is evident that creativity covers several aspects.

Alencar and Fleith (2008) consider that creativity is a complex and dynamic phenomenon that contributes to the expression of a person and can be influenced by the environment in which he finds himself, such as the sociohistorical-cultural, educational institutions, the workplace, among others. However, the same factors that stimulate can also inhibit creativity, moreover, one cannot disregard the individual's personality. In this context, according to the authors, the academia is one of the main factors that influence the formation and development of the creative profile. However, a college education still provides little to the expression of the ability to create and often neither encourage, nor constrain the development and expression of these skills.

In order to certify a more applied creative production, Oech (1994) propose four characters - Explorer, Artist, Judge and Warrior - featuring the profile of an individual in the creative process. Despite this, he believes that all individuals have the capacity to develop or repress themselves, even though, there are usually only a few features predominate.
Among the diverse courses offered by universities, engineering courses by their nature should include a set of potentially creative individuals. During the training of an engineer it should be noted the development of creative profile from the beginning to the end to analyze how academics factors can influence the process of its formation. Given the different types of creative profile that an individual may have and develop, this paper seeks, therefore, to answer the open-ended problem: "What is the profile of the creative students of Undergraduate Industrial Engineering and Civil Engineering at a Federal University?".

According to David et al. (2011), higher education, compared to primary and secondary education, has been the focus of less research related to creativity. Therefore, this paper aims to understand the creative profile of undergraduate students of engineering courses in a Federal University based on the classification proposed by Roger Von Oech, due to it allows an easier identification of creative profiles, and examines whether there is a transformation process experienced by students during the academic.

To explore the discussion presented above, it follows the following sequence. Besides this section of introductory character, in the second section theorical basis will be discusses, followed by the research method, analysis of the results obtained and, finally, the concluding remarks are reported. 


\section{Literature review}

The current scenario of demand and market competition requires companies to renew in short periods of time. This fact goes against the more discussed topic today, which is innovation. For González et al. (2012), the innovation model known as Closed Innovation is being replaced by new model called the Open Innovation. Adding external knowledge to internal knowledge provides value and competitive advantages for organizations that adopt this model of innovation.

However, to give support to the organization in planning of his new products, there is a need to rethink the company in its Product Development Process (PDP). According to Amaral and Rozenfeld (2001), the PDP can be greatly benefited with the knowledge management, and with that management, there is an important creative character that essentially depends on the skills and knowledge of each person. However, according to the authors, in order to that knowledge management to be carried out effectively, there are several other aspects that influence that, for example culture and capabilities that each person possesses, leading to study the individual and group creativity.

The creativity valuing as a subjective factor promoted a leverage of diverse currents of thought due to the diversity of knowledge and opinions on the subject, thereby increasing the researches about it. According to Alencar and Fleith (2003) until the 70's the creativity was studied with a psychoanalyst approach, returning the preconscious processes to the creative being explosion.

However, the current research consider the concept of creativity as very complex and that differ according to the vision of each author, for example, on spatio-temporal context and socioeconomic status (DAVID et al., 2011).

Amabile (2012) and Ritter, Van Baaren and Dijksterhuis (2012) believe that all people have the capacity to be creative, and one of the strategies used to foster creativity, encouraging individuals to generate a continuous flow of innovative ideas, is the application of creativity techniques. The use of techniques to encourage the pursuit of abstraction, the association, the escape from reality in order to contribute to increased generation of ideas and solutions to problems.

About the concept of creativity, Csikszentmihalyi (1999) states that the creative process is a systemic phenomenon, not an individual, which evolves according to the potential of the environment. This definition that creativity depends on the environment in which the individual belongs is still defended by many authors as Ferreira and Candeias (2007), Runco (2007) and Tremblay (2011).

\subsection{Creative potential}

Creativity is the production of a new and appropriate response, product or solution for a task that is open.
However, the answer must be new and not just different. A meaningless speech from a schizophrenic person can be considered new, but few consider creative (AMABILE, 2012).

It is also known that creativity is a skill inherent in the individual and as a skill it is capable of development (ALENCAR; FLEITH, 2003). This ability to develop creativity is called creative potential. According to Oliveira (2010, p. 84) "creativity needs to be exercised with persistence, using existing techniques for this and thinking about strategies that assist in the development of creative potential."

The literature indicated several factors inhibitors and enhancers of creativity (MARINHO et al., 2012). One of the most discussed is the environment in which the individual belongs, that regards the resources that are available, the organizational environment, welfare, and other aspects involved in the environment.

According to Marinho et al. (2012), the main stimulating factors are: suitable environment, cultural organization, multidisciplinary, interdisciplinary, breaking patterns and open mind, confidence, motivation and autonomy. On the other hand, the inhibiting factors discussed in his research are: paradigms, conflicts, pressure to create, a high level of academic stress and tension in performing activities.

In a study conducted by Freire et al. (2012) were identified 24 major motivators factors of creativity in education addressed in academic work, the study is focused on early childhood education, but it is easily visible the similarities with the higher education. Among them it is pointed out: create a rich and diverse environment, encourage a reasonable independence; stimulate the production of ideas; induce the discovery learning and global understanding.

\subsection{Study about the creative profile}

The first studies about creativity regarded it as a gift brought from birth. In this perspective, a person was creative or not (GURGEL, 2006). In that way, studies about this subject for a significant period of time were straight by the pursuit of the creative individual, how to identify this individual and what features made him creative.

However, as stated earlier, the recent studies have found that creativity is something inherent in every person and that there were factors that could inhibit or stimulate the creativity of the person, such as personal characteristics have been considered relevant, the analysis of the creative profile also happened to be a subject of study. These factors should be manipulated in order to converge to the characteristics of the individual for a creative profile.

Nakano and Wechsler (2006), in his research that investigated high school students and higher education, pointed out characteristics of the individual creative 
beyond the four cognitive characteristics of Torrance (1976) - fluency, flexibility, originality and elaboration - Nine emotional characteristics: expression of emotions, fantasy, movement, unusual perspective, internal perspective, use of context, combinations, extension limits and expressive titles.

According to Oech (1994) the creative individual mind is flexible and has the ability to use different kinds of thinking when it is required form it. Moreover, the creative person is critical, rigorous, firm and determined. Based on these observed characteristics, he defined four roles to represent the creative process - Explorer, Artist, Judge and Warrior - different, each one with a specific way of thinking.

The role of the Explorer is to seek new things and venture into the unknown. A holistic view and diversity of information are essential in this role and have the expertise in just an area will function as an inhibiting factor for this profile.

To be an Artist, the individual must have the ability to transform information, standards and ideas of new things. To do it, they have to have a different look on things to see beyond what is exposed and always escape the routine and restrictions.

The Judge takes the critical position of the generated ideas He will decide whether the idea should be put into practice or not and whether to make any changes. Therefore, the judge must be aware of the restrictions involved in that idea, but not very arresting in this activity so it does not be supercritical.

Once the Judge approves the idea, the role of the Warrior is to put it into practice and ensure its success. Furthermore, he will give feedback to the other characters if the idea still needs some change. For this, the warrior must be fearless and confident, and most importantly, have conviction in what is being proposed.

According to the author "[...] a striking deficiency in any one of them can spell trouble in sight." (OECH, 1994, p. 147). In others words, for the materialization of a creative individual, it is necessary the balance of all the characters and know how to express them in the appropriate situation.

There are still other creative profile ratings as, for example, the Basandur (PINTO, 1996) which classifies the creative profile into four types: the Generator, the Conceptualizer, the Optimizer and the Implementer.

The first, the Generator, is an individual who absorbs knowledge of the environment where they live and learn from their experiences of life, using this knowledge to imagine different possibilities and thus speculate on new ideas. As for the Conceptualizer, he has a theoretical basis, which acquires knowledge through the definition of the problem, so he tends to synthesize facts and generate different hypotheses and theories. The Optimizer is someone who seeks practical solutions, organizing concrete implementation tactics and are by nature problem solvers.
Finally, the Implementer, who acts in the finalization of the problem, gain knowledge through practical experience and it is the last stage of creative problem solving. This classification of creative profile suggested by the author shows similarity with the proposal by Oech.

\section{Research method}

The method used can be characterized regarding the goal as descriptive, because of the mention of the facts and by the detailed explanation do profile creative (MIGUEL, 2010). Considering the scientific approach, that classify in qualitative, quantitative and qualitative-quantitative (CRESWELL, 2010) this research approach is considered qualitative-quantitative, because of that was necessary the use of quantitative and qualitative techniques to obtain the research results.

Besides the above mentioned, the research presents an applied nature, according to Turrioni and Mello (2012), such a statement is validated by the fact that the research is characterized by having a practical profile.

At the beginning it was administered a literature review in order to understand more about the subject matter. To such review, met a search tools were used from the portal CAPES - Coordenação de Aperfeiçoamento de Pessoal de nível Superior - but also in other national and international portals. In these research bases it was inserted keywords of the article, such as "Criatividade", "Potencial Criativo", "Perfil Criativo", "Formação Acadêmica" e "Graduação", as well as their translations, "Creativity", "Creative Potential", "Creative Profile", "Academic Formation" e "Graduation".

Based on the book A Kick in the Seat of the Pants: Using Your Explorer, Artist, Judge, and Warrior to Be More Creative by the author Roger von Oech and in order to raise the creative profile in engineering courses, it was developed a questionnaire with ten questions in which each question had four alternatives that represented the four characters described by the author. The questionnaire was administered in a fair science, technology and culture promoted by the same university researched.

Against the result, changes were made to adapt, resulting in a total of seven questions, namely: (1) What characteristic below do you most identify?; (2) In a group work you ...; (3) What would do you do if you were lost in a forest with a group of friends ...; (4) In front of an idea you ...; (5) When you want to achieve a goal, what is your attitude?; (6) In your house you are asked for more ...; (7) You receive an offer to travel, then:.

This new setting was applied in a group to check the influence of the order of the alternatives. With the negative result, did not was changed the order. The redesigned questionnaire was administered to 382 undergraduate students in engineering of Technology Center of a Federal University. Under such conditions, from the analysis of 
the data it was identified how he creative profile in these courses is.

\section{The analysis of the data}

The questionnaires were conducted during the first half of 2013 and reached 382 students at the Center of Technology in a Federal University, being 180 of Industrial Engineering course, 202 of Civil Engineering course, in a total of 392 and 615 , respectively, of active students in each course.

For Industrial Engineering course the predominant profile in its undergraduates is the Judge, outlining around $40 \%$ of students in both periods investigated. As for Civil Engineering, the predominant feature in the first six periods is the Warrior, with about $51 \%$, demonstrating the decay after two periods in favor of Judge, now with $59.9 \%$ of dominance.

\subsection{Creative profile of students per course per semester}

Forming a trend in the creative profile during the academic background of students, it will be presented in the following figures, the relationship between the students admission period with the overall percentage of each of the creative process characteristics represented by the characters: Explorer, Artist, Judge and Warrior.

Looking at Figure 1, it is observed that the eight periods analyzed for the Industrial Engineering course, the profile named as the Judge show the most present characteristic. Thus, it can be noticed in accordance with the curriculum of the course that students stop having technological disciplines to have disciplines focused on the human factor and managers, so conditioning their thoughts to take better decisions. However, the profile called Artist is less influential since the stimulus of innovation is not encouraged, using only standard formulas and conditioning them to think in a standardized manner.

Examining the Figure 2 in the same periods, it is noticeable that the Artist is again the characteristic less present in the students during their training for the same reasons as above. However, unlike the Industrial Engineering course, the predominant characteristic is known as the Warrior since the students are trained to implement already developed techniques.

From the processing data, it been observed that in many cases there were undergraduates who had more of one creative profile. Therefore, it was necessary to relate the quantities of multiple profiles presented in each course and compare them with the total amount of simple profiles, which can be seen in Table 1.

When analyzing the data, it was observed that there is a small percentage of students who have multiple profiles compared to total sample. Besides the above mentioned, it can be seen that there is often a need for teamwork, during

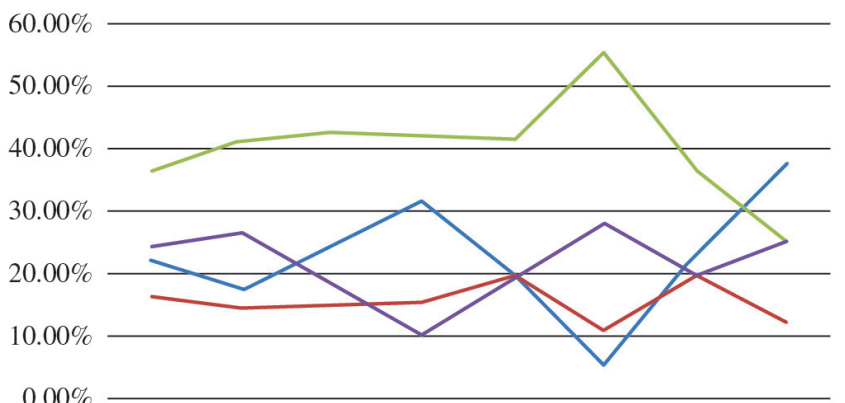

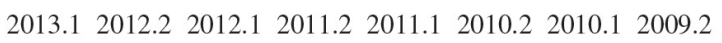

- Explorer — Artist — Judge — Warrior

Figure 1. Trend of the creative profile in Industrial Engineering course per semester of admission.

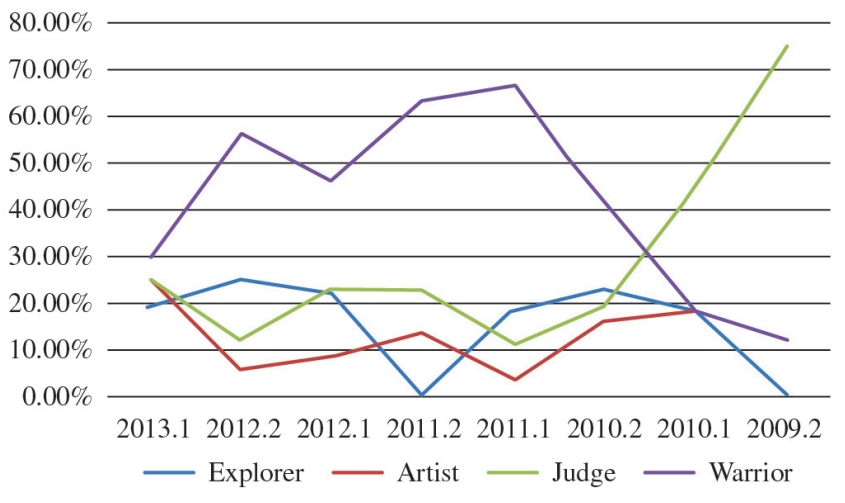

Figure 2. Trend of the creative profile in Civil Engineering course per semester of admission.

Table 1. Participation of multiple profiles.

\begin{tabular}{|l|c|c|c|}
\hline \multicolumn{1}{|c|}{ Course } & Only & Double & Triple \\
\hline Industrial Engineering & 71,7 & 15,0 & 13,3 \\
\hline Civil Engineering & 80,7 & 10,9 & 8,4 \\
\hline
\end{tabular}

the period of graduation, so that the creative process can be developed more efficiently. Under such conditions, the nondevelopment of the plurality of profiles during graduation may end up damaging the future career of the students.

\subsection{Comparing the creative profile surveyed at the Engineerings}

In order to explore the surveyed values, it was developed the Figure 3, which shows that the evolutionary trend of the two studied Engineerings creative. Considering the above, one can see that the Warrior and Judge profiles, referring to the final features of the creative process are the ones that are most predominant among them. However, there is an increase in the participation of the Judge in the final semesters of training since the maturity acquired during the graduation period gives students a greater critical sense. 


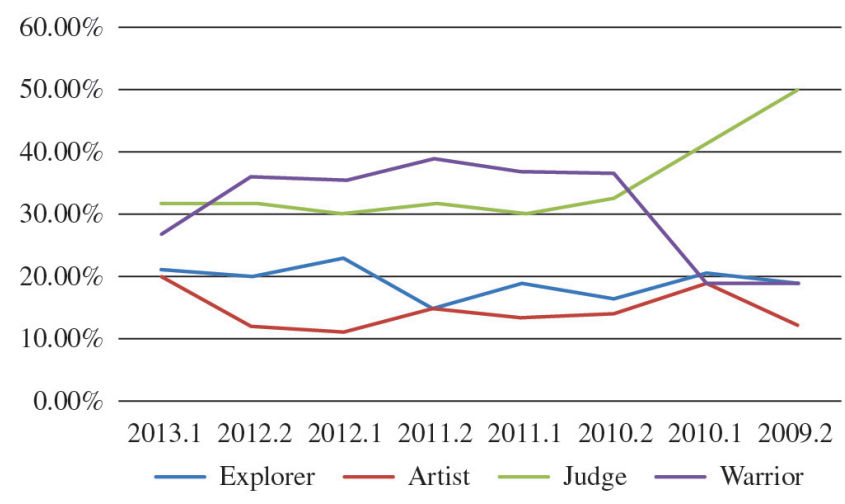

Figure 3. Profile Creative in Engineering's students per semester of admission.

As discussed earlier in Figures 1 and 2, and as can be seen in Figure 3, the Artist profile is still the least important among the students surveyed. In this context, we can say that the pedagogical approaches adopted by teachers in the surveyed courses generally did not stimulate the breakdown of paradigms, so that during the academic carrier it remains practically constant. In front this reality, finally we have the profile Explorer which presents constant around 20\% during the graduation courses.

\section{Final considerations and recommendations}

Creativity is a widely discussed topic and it has gained importance in recent years, mainly as regards to the profile of creativity developed by people during the lifetime. In the current scientific-technical era, creative professionals, who are able to generate ideas and most effective solutions to innovate in the creation of products and processes, are increasingly required. Therefore, understanding the creative development of an individual is becoming increasingly important to suit this market which is constantly changing.

Education institutions have a crucial role in the construction of the creative profile of a future professional. Thus, the discovery of the student's creative profile can be used in a way that facilitates the detection of strategic points to work the potential developing and creative profile that each individual carries.

However, from the research conducted in a Federal University, it was observed that the obtained data in the courses of Industrial Engineering and Civil Engineering is still difficult to find and prepare professionals who are able to interpret harmonically all profiles proposed by Oech. However, it must be taken into account that the curriculum and pedagogical approaches adopted by the professors, directly affect this development, being it positive or negative.

However, the study suffered some limitations during the questionnaires application because some classes of the surveyed courses had few students and some professors were not favorable for implementation.

Nevertheless, despite the limitations, it was observed that the study brought a greater insight into the student's creative profile of the courses of Industrial Engineering and Civil Engineering.

In addition to providing an analysis of the evolution of creative profiles during the training period, it enabled the discovery that it is necessary to reflect on academic education - curriculum, content of offered components and pedagogical approach of teaching - to provide a stimulus to the development of creative potential and develop them in a more harmonious way, so it attends the new requirements of the market.

Taking into account the issues raised, it is possible to envision future work on issues related to the creative potential of teachers, such as: what the role of teachers in developing the creative potential of the students is; what the pedagogical practices that enable the development of technical skills while developing the creative ability of students are; as teachers assess the creative profile of their students; as students assess the creative profile of their teachers; what the predominant profile of teachers is, and how it influences the approach applied in the classroom. There are some thoughts that were concluded in this study as concern that the labor market increasingly demands from engineers with high technical knowledge mutually with creative skills.

\section{References}

ALENCAR, E. M. L. S.; FLEITH, D. S, Criatividade Pessoal: Fatores Facilitadores e Inibidores Segundo Estudantes de Engenharia. Magis - Revista Internacional de Investigación en Educación, Bogotá, v. 1, p. 113126, 2008.

ALENCAR, E. M. L. S.; FLEITH, D. S. Contribuições teóricas recentes ao estudo da criatividade. Psicologia: Teoria e Pesquisa, v. 19, n. 1, p. 1-8, abr. 2003. Available from: <http://www.scielo.br/pdf/ptp/v19n1/a02v19n1.pdf>. Accessed in: 26 jun. 2013.

AMABILE, T. M. Componential theory of creativity. Harvard Business School Working Paper, n. 12-096, 2012. Available from: <http://www.hbs.edu/faculty/Publication $\% 20$ Files/12-096.pdf>. Accessed in: 18 jul. 2013.

AMARAL, D. C.; ROZENFELD, H. Explicit Knowledge Management on the Product Development Process. Product: Management \& Development, v. 1, p. 49-58, set. 2001.

CRESWELL, J. W. Projeto de Pesquisa: métodos qualitativo, quantitativo e misto. 3. ed. Porto Alegre: Artmed, 2010.

CSIKSZENTMIHALYI, M. Implications of a systems perspective for study of creativity. In: STERNBERG, R. 
J. (Org.). Handbook of creativity. New York: Cambridge University Presss, 1999.

DAVID, A. P. et al. Competências criativas no ensino superior. In: WESCHSLER, S.; NAKANO, T. (Org.). Criatividade no ensino superior: uma perspectiva internacional. São Paulo: Vetor, 2011. cap. 1, p. 14-53.

FERREIRA, E. R.; CANDEIAS, A. A. Da pessoa criativa à atitude criativa: estudo de um percurso. In: CANDEIAS, A. A.; ALMEIDA, L. S. (Org.). Inteligência humana. Coimbra: Quarteto, 2007. cap. 28, p. 497-510.

FREIRE, A. et al. Desenvolvimento do potencial criativo: uma revisão bibliográfica sistemática e propostas de boas práticas. In: ENCONTRO NACIONAL DE ENGENHARIA DE PRODUCAO, 32., 2012, Bento Gonçalves. Anais... Bento Gonçalves: ABEPRO, 2012.

GONZÁLEZ, M. O. A. et al. Open innovation practices in the development of wind energy supply chain: an exploratory analysis of the literature. Product: Management \& Development, v. 10, p. 104-111, dec. 2012.

GURGEL, M. F. Criatividade e inovação: uma proposta de gestão da criatividade para o desenvolvimento da inovação. 2006. 203 f. Dissertação (Mestrado em Engenharia de Produção)-Universidade Federal do Rio de Janeiro, Rio de Janeiro, 2006.

MARINHO, E. S. et al. Relação entre criatividade e inovação de produtos: uma revisão bibliográfica sistemática. In: ENCONTRO NACIONAL DE ENGENHARIA DE PRODUCAO, 32., 2012, Bento Gonçalves. Anais... Bento Gonçalves: ABEPRO, 2012.

MIGUEL, P. A. C. (Org.). Metodologia de pesquisa em engenharia de produção e operações. Rio de Janeiro: Campus, 2010.
NAKANO, T. C.; WECHSLER, S. M. O percurso da criatividade figural do Ensino médio ao ensino superior. Boletim de Psicologia, v. 56, n. 125, p. 205-219, 2006.

$\mathrm{OECH}, \mathrm{R}$. V. Um chute na rotina: os quatro papéis essenciais do processo criativo. Tradução de Cecília Prada. São Paulo: Cultura, 1994.

OLIVEIRA, Z. M. F. Fatores influentes no desenvolvimento do potencial criativo. Estudos de Psicologia, v. 27, n. 1, p. 83-92, mar. 2010. http://dx.doi.org/10.1590/S0103$166 \times 2010000100010$

PINTO, J. A. N. Abordagem do ato de criatividade Serendíptica segundo características próprias de comportamento do indivíduo. 1996. Tese (Doutorado em Engenharia de Produção)-Universidade Federal de Santa Catarina, Florianópolis, 1996.

RITTER, S. M.; VAN BAAREN, R. B.; DIJKSTERHUIS, A. Creativity: The role of unconscious processes in idea generation and idea selection. Thinking Skills and Creativity, v. 7, p. 21-27, 2012.

RUNCO, M. A. Creativity. Theories and Themes: Research, Development and Practice. Amsterdam: Elsevier, 2007.

TORRANCE, E. P. Criatividade: medidas, testes e avaliações. São Paulo: Ibrasa, 1976.

TREMBLAY, G. Criatividade e pensamento crítico. Revista Brasileira de Ciências da Comunicação, v. 34, n. 1, p. 255-266, jan./jun. 2011. http://dx.doi.org/10.1590/S180958442011000100013

TURRIONI, J. B.; MELLO, C. H. P. Metodologia de pesquisa em engenharia de produção. Itajubá: UNIFEI, 2012. 